\title{
Quantitative analysis on the environmental impact of large-scale water transfer project on water resource area in a changing environment
}

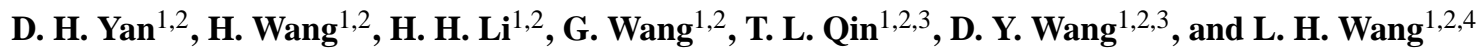 \\ ${ }^{1}$ State Key Laboratory of Simulation and Regulation of Water Cycle in River Basin, China Institute of Water Resources and \\ Hydropower Research, Beijing, 100038, China \\ ${ }^{2}$ Water Resources Department, China Institute of Water Resources and Hydropower Research, Beijing, 100038, China \\ ${ }^{3}$ Environmental Science and Engineering Department, Donghua University, Shanghai, 201620, China \\ ${ }^{4}$ School of Hydraulic Engineering, Dalian University of Technology, Dalian, 116023, China
}

Correspondence to: G. Wang (hanhehebest@163.com)

Received: 19 October 2011 - Published in Hydrol. Earth Syst. Sci. Discuss.: 30 November 2011

Revised: 6 July 2012 - Accepted: 10 July 2012 - Published: 13 August 2012

\begin{abstract}
The interbasin long-distance water transfer project is key support for the reasonable allocation of water resources in a large-scale area, which can optimize the spatiotemporal change of water resources to secure the amount of water available. Large-scale water transfer projects have a deep influence on ecosystems; besides, global climate change causes uncertainty and additive effect of the environmental impact of water transfer projects. Therefore, how to assess the ecological and environmental impact of megaprojects in both construction and operation phases has triggered a lot of attention. The water-output area of the western route of China's South-North Water Transfer Project was taken as the study area of the present article. According to relevant evaluation principles and on the basis of background analysis, we identified the influencing factors and established the diagnostic index system. The climate-hydrology-ecology coupled simulation model was used to simulate and predict ecological and environmental responses of the water resource area in a changing environment. The emphasis of impact evaluation was placed on the reservoir construction and operation scheduling, representative river corridors and wetlands, natural reserves and the water environment below the dam sites. In the end, an overall evaluation of the comprehensive influence of the project was conducted. The research results were as follows: the environmental impacts of the western route project in the water resource area were concentrated on two aspects: the permanent destruction of vegetation during
\end{abstract}

the phase of dam construction and river impoundment, and the significant influence on the hydrological situation of natural river corridor after the implementation of water extraction. The impact on local climate, vegetation ecology, typical wetlands, natural reserves and the water environment of river basins below the dam sites was small.

\section{Introduction}

With the increase of the world's population, the rapid development of agriculture and industry and the increasing urbanization, the uneven spatio-temporal distribution of water resources and its quality deteriorate. To address the serious limitation of water resources to economic development, many countries have undertaken water transfer projects. From 1940 to 1980 , the world witnessed the peak period of the construction of large-scale long-distance interbasin water transfer projects (Yang, 2003; Wang, 2009). After 1980, with the uprising consciousness of environmental protection, people became cautious of the construction of water transfer projects and a series of reports came out concerning the negative ecological impacts of both construction and operation of these projects (Davies et al., 1992; Meador, 1992; Nardini et al., 1997). Since then, countries all over the world have begun to conduct environmental impact assessment of water transfer projects, and carried out thorough research on related 
environmental issues and ecological influence (Graf, 2006; Morais, 2008; Braatne et al., 2008; Kittinger et al., 2009; Baran and Myschowoda, 2009; Growns et al., 2009; Wu et al., 2010; Olden and Naiman, 2010). At the same time, laws and regulations in terms of the construction and operation of water transfer projects were published so as to mitigate and even prevent the ecological and environmental problems (Yang, 2003; Wang, 2009). Besides, studies on evaluation of ecological and environmental influence of water transfer projects have gradually developed into an important field (Doledec et al., 1996; Bombino et al., 2006; Shah and Kumar, 2008). Meanwhile, accompanied by the aggravation of the global climate change, the evaluation concerning the environmental influence of the water transfer project in a changing environment has become increasingly valued, and a few studies in this field were carried out (Zeilhofer and Moura, 2009; Olden and Naiman, 2010; Döll and Zhang, 2010; Moiwo et al., 2010; Pittock and Finlayson, 2011).

Megaprojects, especially those which cross rivers and are of long distance, are all huge systematic projects. They have a large span of space and time and therefore impose a broad array of impacts on the environment and ecosystems of a river basin (Petts, 1984; Casado et al., 1989; Poff et al., 1997; Rosenberg et al., 1997; Friedl and Wüest, 2002; Brismar, 2004; Burke et al., 2009). What is more, the environmental and ecological influence of project under the background of global climate change is extremely complex; thus, there is considerable uncertainty. Present relevant studies are short of global, comprehensive and systematic research as they are focused on a certain aspect of the environmental influence, such as the hydrological situation, pollutant transport patterns and biodiversity (Morais, 2008; Hu et al., 2008; Koutsos et al., 2010; Ouyang et al., 2011), or they are targeted at a certain area, such as the water-output area, water-intake area and the river delta (Xu et al., 2011; Ligon et al., 2011; Restrepo and Cantera, 2011). The climate change aspect has been inadequately treated in the environmental impact assessment of large water transfer projects. Judging from the experiences of existing water transfer projects, the estimation of their impact on ecology and environment is insufficient, and the negative influence of projects in the phase of operation is becoming increasingly significant. The western route of China's South-North Water Transfer Project (SNWTP) water-output area is located in the first topographic ladder of China Qinghai-Tibet Plateau, an ecological fragile region and sensitive area of global climate change. Therefore, environmental and ecological impact assessment of this area is of great importance and has triggered a lot of concern (Yang et al., 2002; Berkoff, 2003; Ghassemi and White, 2006).

In the present article, some explorations of the evaluation of the ecological influence of the western route project on its water-output area in a changing climate were conducted. This study aims to contribute to show how, and to what extent, the western route project of SNWTP will impact ecology and environment in water resource area and regions related to water transfer. The specific objectives of this paper are to evaluate the influence of the water transfer (1) on the local climate of the water resource area after reservoir construction; (2) on the hydrological situation of typical dewatered river reaches; (3) on typical wetlands and natural reserves; and (4) on water environment below the dam sites.

\section{Materials and methods}

\subsection{The study area}

The first stage of western route project of SNWTP is located in the southeast edge of the Qinghai-Tibet Plateau $\left(99^{\circ} 20^{\prime}-\right.$ $102^{\circ} 10^{\prime} \mathrm{E}, 31^{\circ} 30^{\prime}-33^{\circ} 20^{\prime} \mathrm{N}$ ). It covers seven counties in three provinces, i.e. Qinghai, Sichuan and Gansu province. This region is characterized by a cold and dry highland climate with an elevation above $3000 \mathrm{~m}$. The average temperatures vary between minus $5-6{ }^{\circ} \mathrm{C}$, and the annual precipitation amount is approximately $500-600 \mathrm{~mm}$. The region has alternating dry and wet seasons exhibiting a distinct seasonality. The water resource area is located in the upstream regions of Yalong River and Dadu River, two main tributaries of the upper Yangtze River. The dam sites of water transfer are located in Ganzi section at the upper reaches of the Yalong River's mainstream; in Daqu and Niqu sections of the upper reaches of the Xianshuihe River, a branch of the Yalong River; in Sequ and Duke sections of the upper reaches of Chuosijia River, the west branch of the Dadu River; and in Make and Ake sections of the upper reaches of Zumuzu River, the east branch of Dadu River. Seven water transfer reservoirs are scheduled to be constructed: Reba, Aan, Renda, Luoruo, Zhuanda, Huona and Keke, with catchments ranging between $1,470-26,535 \mathrm{~km}^{2}$. Figure 1 shows the arrangement of the western route project.

The water-output area of the western route project is the ecological shield of the upper stream of Yangtze River. It is also an ecological fragile zone with severe ecological and environmental problems such as deforestation, glacier recession, lake shrinkage and salinization, meadowing of swamps and other environmental issues resulting from climate change as well as human activities. While the Qinghai-Tibet Plateau is one of the most sensitive regions to global climate change (Liu and Chen, 2000), the hydrogeological cycles and biological productivity of the water-output area are sensitive to Asian monsoon variations (Ji et al., 2005). Therefore, the response of local climate to regional land-use change due to reservoir construction should be considered. It is probable that the construction and running of the project could impose an influence of various degrees on the eco-environment and society and economy of this area. To carry out an objective eco-environmental evaluation of the western route project on the area in a changing climate is of great significance for putting forward a scientific and systematic hydrological 


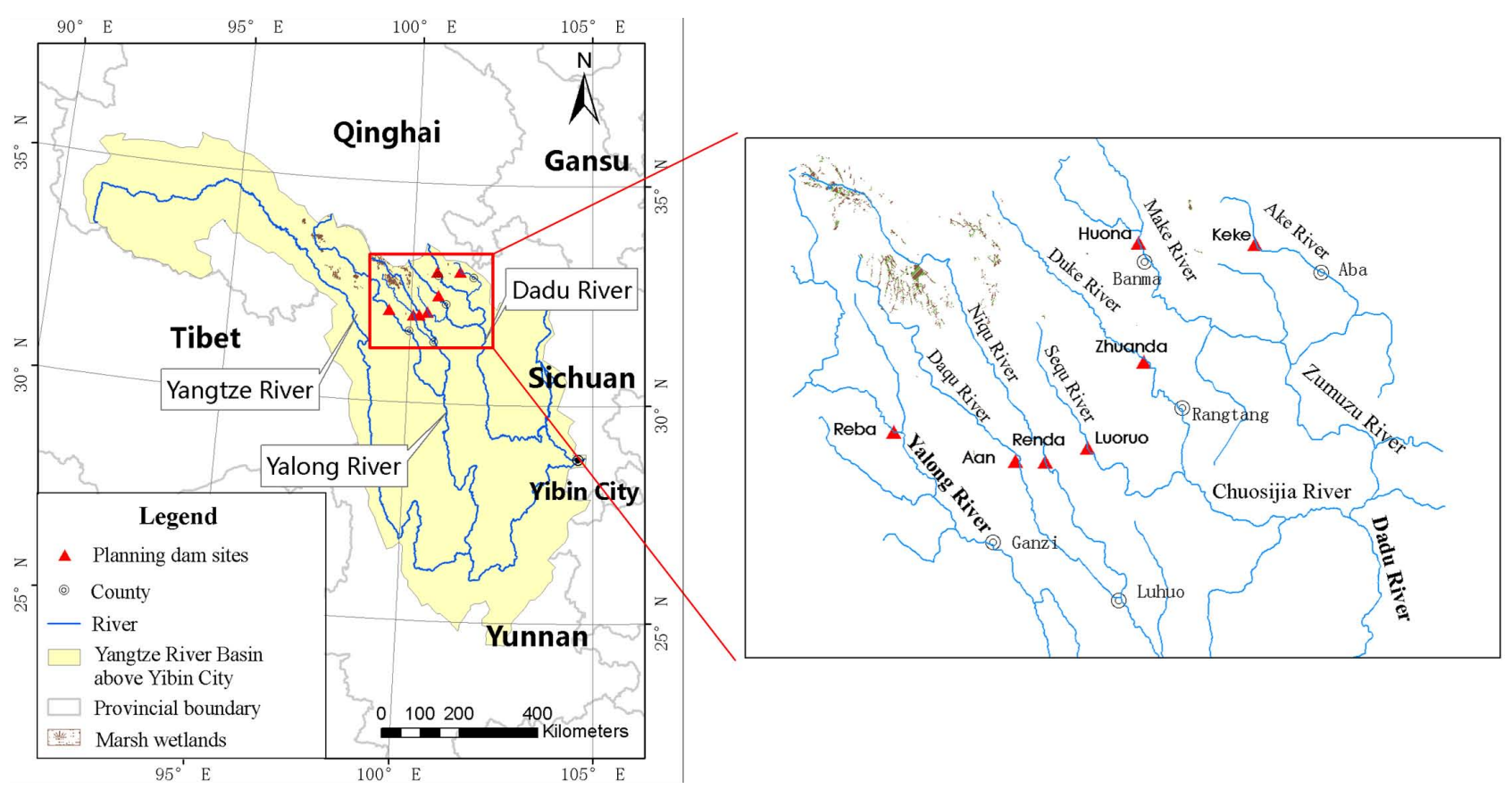

Fig. 1. Arrangement diagram of the project.

control plan, so as to give reasonable guidance to the planning, construction and operation of the project.

\subsection{Main considerations for the evaluation}

According to the characteristics of large-scale water transfer projects, special importance was attached to the correlation and superimposed influence between projects and the interrelation among all kinds of ecological factors closely related to water transfer in the process of evaluation. In view of the strategic level, the construction and operation of the whole water transfer project were integrated into the evaluation system.

First of all, background analysis on the eco-environment of the study area was conducted based on present meteorological, hydrological, soil and vegetation information and the data collected by field survey. The influence identification and evaluation indices were determined based on relevant evaluation criteria. Then, based on the climate-hydrologyecology coupled simulation model in conjunction with statistical methods, the influence analysis and quantitative evaluation were performed focusing on the four specific objectives of this paper. In the end, a comprehensive influence assessment on the ecological evolution of the water resource area was conducted.

\subsection{Formulation of the evaluation index system}

Firstly, eight primary indices of geography, atmosphere, hydrology, soil, biology, population and economy, natural disaster and land deterioration including 137 secondary indices were employed in order to give a comprehensive and objective characterization of the ecology and environment of the upper stream of Yangtze River. And a hierarchical model was built to form a general characterization index system. Then, the 1-9 scale method in analytic hierarchy process (Saaty, 1987) was applied to mark the importance of the indices and build the structural judgment matrix for the possible influence of the western route project on the environment. Five primary indices (i.e. atmosphere, water, biology, soil, natural disaster and land deterioration) were chosen by analytic hierarchy process, and 32 secondary indices were then determined to form the characterization index system of environment in the water-output area. In the end, given the importance of the 32 indices, the sequence of their weight values and the accessibility of the information as well, four primary indices and 8 secondary indices directly to water transfer were chosen from the characterization index system to form the diagnostic indices of the environmental evolution of the water-output area.

\subsection{Definition of the evaluation scale}

Given the particular geographical location and ecological characteristics of the western route of SNWTP, the influence of the western route project on the water resource area can be divided into three categories: (i) large-scale area oriented to global change (Category I area), i.e. Southeast Asia; (ii) medium-scale area oriented to local water resources allocation (Category II area), i.e. the Yangtze River Basin above Yibin; and (iii) areas apparently influenced by the project 


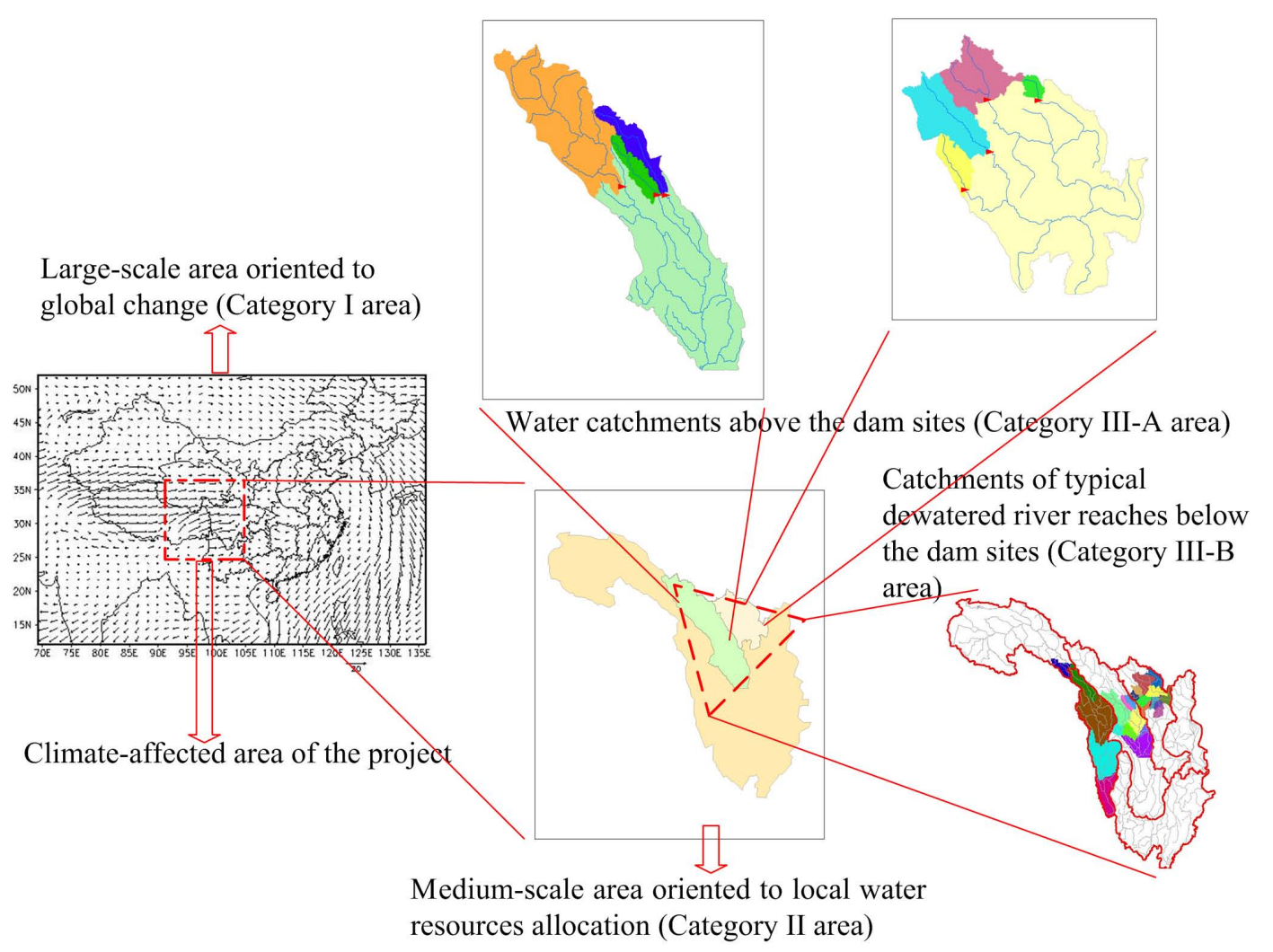

Fig. 2. The spatial scales for evaluation.

(Category III area), which include water catchments above the dam sites (Category III-A area) and typical dewatered reaches below the dam sites (Category III-B area). What is more, underlying surface change may lead to the modification of microclimate conditions; hence, the area of local climate change due to the project should be included (Category III-C area).

Therefore, evaluation was conducted on the following three scales: the Southeast Asia, the Yangtze River Basin above Yibin and the apparently affected areas (see Fig. 2). On the Southeast Asia scale, the main consideration was put on the response of the local environment to global climate change and the influence of underlying surface change on the climate; on the scale of Yangtze River Basin above Yibin, the emphasis of evaluation was placed on the influence of climate change as well as the water transfer on the local water cycle and vegetation; and on the scale of the apparently affected areas, the evaluation was focused on the influence of project on the typical dewatered river reaches below the dam sites and the water storage areas above the dam sites.

\subsection{Development of the climate-hydrology-ecology coupled simulation platform}

To identify the influence of the western route project of SNWTP on the ecology and environment of the water resource area is the premise of the planning of the project, as well as the focus of arguments of stakeholders. Meanwhile, scientific prediction of the changes on the water circulation and environment of related areas is the key to forecast the transferable water amount in the process of project operation. The key technical support for the two practical needs mentioned above requires the development of a climatehydrology-ecology coupled simulation model and a forecast platform with integrated mechanism based on the multilayer observation of hydrology, meteorology/climate and ecology. The simulation platform should possess the following functions: (1) giving historical analogue simulation on the water circulation, ecological and environmental process of the water resource area; (2) identifying the main mechanism of mutual actions among climate, hydrology and ecology; (3) objectively characterizing the key driving mechanism in the water circulation and ecological and environmental evolutions; and (4) simulating those evolutions under various ecohydrological regulation scenarios.

According to some field investigations, the aquatic ecosystem has a relatively simple composition and there are few sensitive species in the water resources area. Therefore, the water transfer project may have subdued effects on the aquatic ecosystem, which is not our major concern in the design of the modeling platform. The ecological process discussed in this paper is mainly limited to terrestrial 


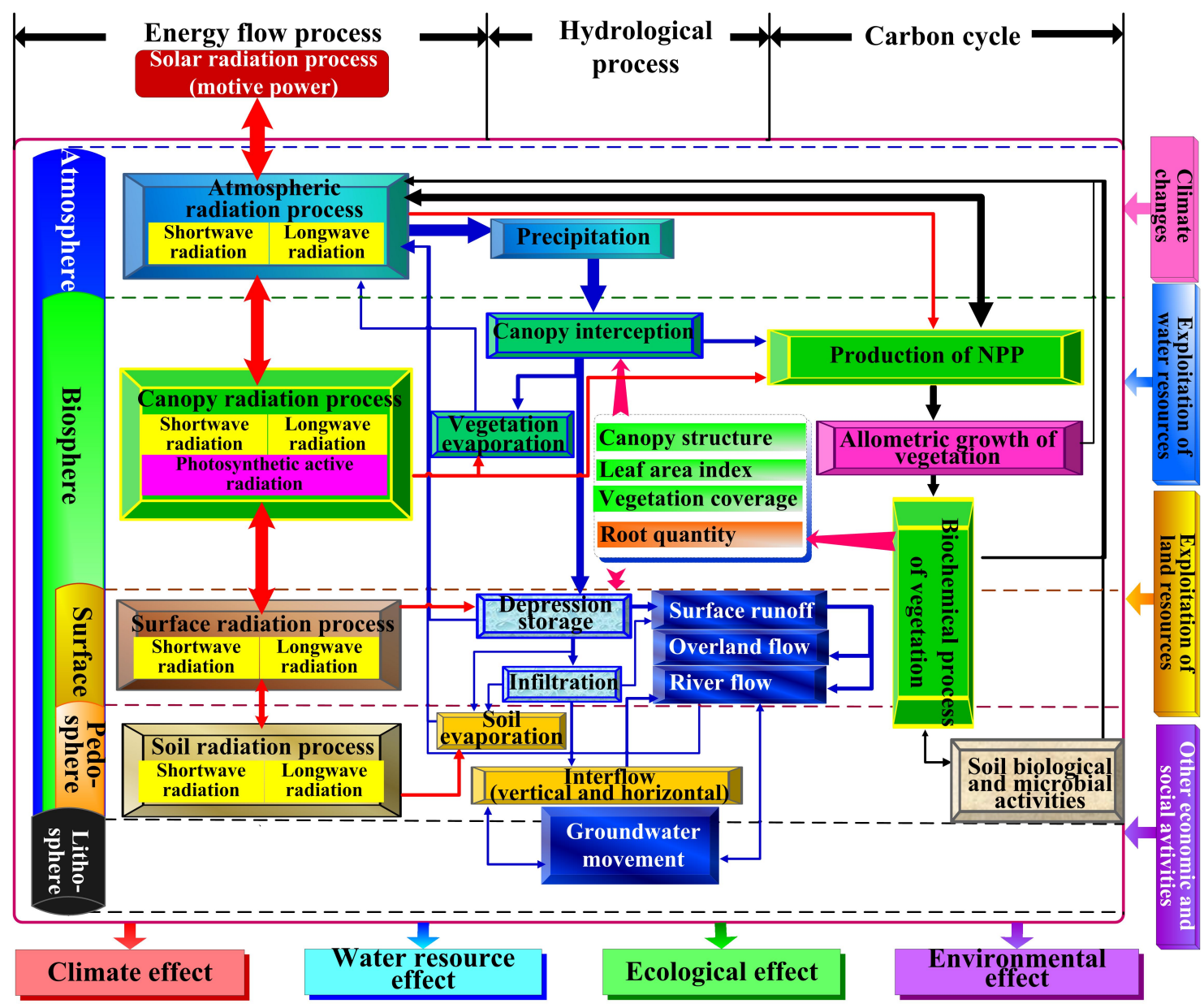

Figure

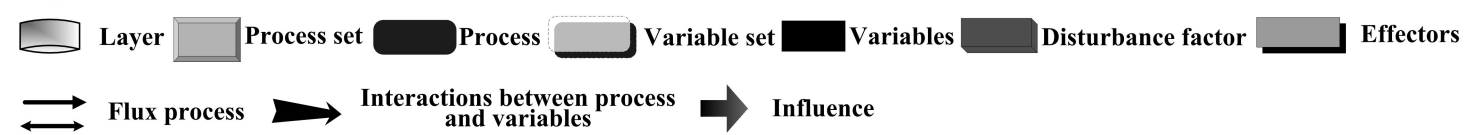

Fig. 3. Framework of climate-hydrology-ecology coupled simulation model.

ecosystems with carbon circulation as the main line. The impact of the project on the aquatic ecosystems (e.g. fish habitats and life cycle) will be revealed by the results of quantitative evaluation on typical dewatered river reaches in Sect. 3.4.2. The framework and mutual actions among energy flow, natural-social water circulation and ecological process are shown in Fig. 3.

A large number of ecological models, hydrological models and climate models with relatively independent modules have been developed worldwide, providing an important module database for the development of a climatehydrology-ecology coupled simulation platform. The capability of each model can be fully utilized through modularization strategies during the establishment of the comprehensive coupled model. In this study, the related modules of the regional climate-weather research and forecasting (CWRF) model and regional climate model version 3 (RegCM3) are selected for the simulation of atmospheric water circulation and energy process (Liang et al., 2005a,b, 2012; Yuan and Liang, 2011; Pal et al., 2007); related modules of the water and energy transfer processes (WEP) model are selected for the simulation of natural hydrological cycle (Jia et al., 2001); a water allocation model is used for the simulation of social water circulation (Zhao et al., 2007); related modules of geoprocess (GEOPRO) model, community land model (CLM) and dynamic global vegetation model (DGVM) are selected for the simulation of natural vegetation (Oleson et al., 2004; Steffen et al., 1996); and related modules of DSSAT are selected for crops (Jones et al., 2003). The essential simulation process and characteristics of the selected prototype models are listed in Table 1. A special subject has been set up for the development of the climate-hydrology-ecology coupled 
Table 1. Selection of essential simulation process and the prototype models.

\begin{tabular}{|c|c|c|c|c|}
\hline Basic process & Simulation process & Prototype models & Characteristics of the models & $\begin{array}{l}\text { Degree of satisfaction of the } \\
\text { research requirement }\end{array}$ \\
\hline $\begin{array}{l}\text { Energy flow } \\
\text { process }\end{array}$ & $\begin{array}{l}\text { Radiation process at the Earth's } \\
\text { surface, sensible heat flux, latent } \\
\text { heat flux, soil canopy heat flux, } \\
\text { etc. }\end{array}$ & CWRF, RegCM3 & $\begin{array}{l}\text { Performing better at the } \\
\text { simulation of energy process; } \\
\text { merely considering the vertical } \\
\text { process }\end{array}$ & $\begin{array}{l}\text { Realizing the energy process } \\
\text { modeling of various layers. }\end{array}$ \\
\hline $\begin{array}{l}\text { Water } \\
\text { circulation } \\
\text { process }\end{array}$ & $\begin{array}{l}\text { Natural surface water process, soil water } \\
\text { canopy interception, } \\
\text { evaporation and transpiration, } \\
\text { hydrological cycle of } \\
\text { process, groundwater process, } \\
\text { overland flow and river flow; } \\
\text { social water circulation of water } \\
\text { intaking, transporting, using, } \\
\text { consuming and draining }\end{array}$ & $\begin{array}{l}\text { WEP, } \\
\text { Reasonable water } \\
\text { allocation model } \\
\text { based on criteria } \\
\text { and optimized } \\
\text { technology }\end{array}$ & $\begin{array}{l}\text { Performing better at both } \\
\text { vertical and horizontal water } \\
\text { circulation processes; inaccurate } \\
\text { in energy process simulation; } \\
\text { and no consideration of the } \\
\text { dynamics of ecological process }\end{array}$ & $\begin{array}{l}\text { Realizing natural-social water } \\
\text { circulation simulation; } \\
\text { providing basic river habitat } \\
\text { data of water level and depth, } \\
\text { flow velocity and quantity }\end{array}$ \\
\hline $\begin{array}{l}\text { Ecological } \\
\text { process }\end{array}$ & $\begin{array}{l}\text { Net primary productivity (NPP), } \\
\text { material distribution and } \\
\text { transportation, competition for } \\
\text { light, reproduction, species } \\
\text { invasion, bioclimatic process, } \\
\text { death and soil organic material } \\
\text { decomposition, simulation of } \\
\text { the growth and succession of } \\
\text { vegetation }\end{array}$ & $\begin{array}{l}\text { GEOPRO, CLM, } \\
\text { DGVM and } \\
\text { DSSAT }\end{array}$ & $\begin{array}{l}\text { GeoPro can perform leaf-scale } \\
\text { simulation; CLM contains a } \\
\text { canopy flux module; DGVM } \\
\text { and DSSAT can simulate the } \\
\text { growth and succession of } \\
\text { natural vegetation and crops, } \\
\text { respectively }\end{array}$ & $\begin{array}{l}\text { Realizing the basic simulation } \\
\text { of ecological process; } \\
\text { quantitatively identifying } \\
\text { ecological and environmental } \\
\text { evolutions }\end{array}$ \\
\hline $\begin{array}{l}\text { Water } \\
\text { environmental } \\
\text { process }\end{array}$ & $\begin{array}{l}\text { Transportation and } \\
\text { transformation process of } \\
\text { pollutants, pollution load and } \\
\text { environment capacity evolution }\end{array}$ & $\begin{array}{l}\text { One-dimensional } \\
\text { dynamic model of } \\
\text { water quality }\end{array}$ & $\begin{array}{l}\text { Performing well at the } \\
\text { simulation of the transportation } \\
\text { and transformation process of } \\
\text { pollutants along rivers. }\end{array}$ & $\begin{array}{l}\text { Realizing basic simulation of } \\
\text { water environment }\end{array}$ \\
\hline
\end{tabular}

model in a research report related to the western route project of SNWTP. ${ }^{1}$ This paper focuses on the main findings with regard to the environmental and ecological impact of the water transfer project.

\section{Results and discussion}

\subsection{The diagnostic index system}

The diagnostic index system includes four primary indices for the criterion level and eight secondary indices for the index level (Table 2). These indices can give about $70 \%$ information of the target level, which can basically meet the demand of the eco-environmental diagnosis of the water resource area of the water transfer project. Relevant indices chosen from the diagnostic indices were used to give quantitative analysis of the influence of the project on the ecology and environment in typical affected areas.

\footnotetext{
${ }^{1}$ A research project (Assessment on the ecological and environmental impact of the western route of SNWTP on the water-output area and comprehensive regulation technologies, Grant agreement no.: 2006BAB04A08) started by the Ministry of Science and Technology of the People's Republic of China in 2006.
}

\subsection{The model performance}

Given the complexity of the model, a step-by-step strategy with multiple processes and scales is adopted for the parameter adjusting and model validation. The NRA reanalysis data from the American National Centers for Environmental Prediction (NCEP) were used to optimize the boundary condition, a key factor in the climate simulation. Precipitation, runoff, net primary productivity (NPP), and chemical oxygen demand (COD) as well as ammonia- $\mathrm{N}\left(\mathrm{NH}_{3}-\mathrm{N}\right)$ were chosen as the simulation variables for the atmospheric process, hydrological process, ecological process and water environmental process, respectively. Data from observation and field investigation are the basis of parameter adjusting. The correlation coefficient, relative error and Nash-Sutcliffe coefficient between simulated and observed values were used to evaluate the model performance. Detailed information on adjusting parameters and validation criterion for each basic process is listed in Table 3. From the results of model validation shown in Table 4, the proposed model performs well and can basically meet the demand of the quantitative evaluation of the environmental impact of the western route project. 
Table 2. Environmental and ecological diagnostic indices of the western route of SNWTP.

\begin{tabular}{lllc}
\hline Target level & Criterion level & Index level & Weight of index \\
\hline Ecological and hydrological & Atmosphere 0.1681 & Annual average temperature & 0.0922 \\
regulation of the water resource & & Annual rainfall & 0.1078 \\
area of the western route of & & Dryness of atmosphere & 0.0938 \\
SNWTP & Water 0.4631 & Ecological flow & 0.1745 \\
& & Area of wetland & 0.1656 \\
& & Runoff coefficient & 0.1344 \\
& Biology 0.2270 & $\gamma$ biodiversity index & 0.1117 \\
& Land deterioration 0.1418 & Soil erosion modulus & 0.1199 \\
\hline
\end{tabular}

Table 3. Information for parameter adjusting.

\begin{tabular}{lllll}
\hline Basic process & Adjusting parameters & $\begin{array}{l}\text { Main basis for } \\
\text { parameter adjusting }\end{array}$ & Validation criteria & Simulation variables \\
\hline $\begin{array}{l}\text { Atmospheric } \\
\text { process }\end{array}$ & Boundary condition & $\begin{array}{l}\text { Boundary } \\
\text { optimization with } \\
\text { reanalysis data }\end{array}$ & $\begin{array}{l}\text { Correlation coefficient no less } \\
\text { than } 0.6\end{array}$ & Precipitation \\
\hline $\begin{array}{l}\text { Hydrological } \\
\text { process }\end{array}$ & $\begin{array}{l}\text { Depression storage, } \\
\text { Manning's roughness } \\
\text { coefficients, soil moisture and } \\
\text { hydraulic conductivity } \\
\text { coefficients }\end{array}$ & $\begin{array}{l}\text { Observation data from } \\
\text { gauging stations; soil } \\
\text { data from field works }\end{array}$ & $\begin{array}{l}\text { Nash-Sutcliffe efficiency index } \\
\text { and correlation coefficient are no } \\
\text { less than } 0.7 \text { and 0.8, } \\
\text { respectively }\end{array}$ & Runoff \\
\hline $\begin{array}{l}\text { Ecological } \\
\text { process }\end{array}$ & $\begin{array}{l}\text { Efficiency of sunlight } \\
\text { utilization, leaf area } \\
\text { index (LAI) }\end{array}$ & $\begin{array}{l}\text { Data from } \\
\text { interpretation of } \\
\text { remote sensing images }\end{array}$ & $\begin{array}{l}\text { Correlation coefficient no less } \\
\text { than } 0.8\end{array}$ & NPP \\
\hline $\begin{array}{l}\text { Water } \\
\text { environmental } \\
\text { process }\end{array}$ & $\begin{array}{l}\text { Degradation coefficient and } \\
\text { loss rate of pollutants }\end{array}$ & $\begin{array}{l}\text { Data from water } \\
\text { quality monitoring }\end{array}$ & $\begin{array}{l}\text { Correlation coefficient no less } \\
\text { than } 0.75\end{array}$ & COD and NH $3-\mathrm{N}$ \\
\hline
\end{tabular}

\subsection{Impact evaluation on the local climate of the water resource area}

The regional climate characteristics are generally dominated by the atmospheric circulation. However, the microclimate conditions may be modified by significant underlying surface change. When the water transfer project is completely implemented, a total amount of 17 billion $\mathrm{m}^{3}$ water will be diverted from the water resource area per year. The total water area of the eight newly built reservoirs will reach $289.9 \mathrm{~km}^{2}$, and the total area of terrestrial land directly affected by the project is approximately $3260 \mathrm{~km}^{2}$. Meanwhile, given the sensitivity of the study area to global climate change, a future climate scenario should be considered in the climate simulation and impact evaluation. Therefore, four scenarios were set up: the control experiment A (current climate without reservoirs) and contrast experiments B (current climate with reservoirs), $\mathrm{C}$ (future climate without reservoirs) and D (future climate with reservoirs). The modeling was carried out in two separate periods of current climate scenario (1993-2002) and future climate scenario (2040-2049) with a 30-km horizontal resolution pattern. The computational domain is the Category III-C area defined in Sect. 2.4. The results are specified as follows:

1. Influence of the project on the local circumfluence and temperature of the water resource area

In the current climate scenario, the reservoir construction increases the wind speed in summer, autumn and winter by $0.3-0.8 \mathrm{~m} \mathrm{~s}^{-1}$. While the wind speed in spring is hardly affected, in the future climate scenario, the influence on wind speed is insignificant, while the influence on the humidity field at the location of $2 \mathrm{~m}$ is significant, which is reflected by the decrease of humidity in the northwest and increase in the Sichuan region in the east.

In the current climate scenario, the reservoir construction has no impact on the spatial distribution of local average temperature. The temporal change of temperature is as follows: after the reservoir construction, the temperature in spring, autumn and winter increases, and winter, with an annual increase of $0.15^{\circ} \mathrm{C}$, is the most significant; in the future climate scenario, the project 
Table 4. Results of model validation.

\begin{tabular}{llcrc}
\hline Scale & Variable & $\begin{array}{c}\text { Correlation } \\
\text { coefficient }\end{array}$ & Relative error (\%) & $\begin{array}{c}\text { Nash-Sutcliffe } \\
\text { coefficient }\end{array}$ \\
\hline Large-scale & Rainfall & $\geq 0.65$ & $\leq 10.30$ & - \\
& Temperature & $\geq 0.89$ & $\leq 4.20$ & - \\
\hline Medium-scale & Runoff & $\geq 0.85$ & $\leq 5.29$ & $\geq 0.72$ \\
& NPP & $\geq 0.81$ & $\leq 7.40$ & - \\
\hline Small-scale & Runoff & $\geq 0.90$ & $\leq 8.27$ & $\geq 0.75$ \\
& NPP & $\geq 0.86$ & $\leq 6.89$ & - \\
& Vegetation type & $\geq 0.70$ & $\leq 13.65$ & - \\
& COD & $\geq 0.78$ & - & - \\
& $\mathrm{NH}_{3}-\mathrm{N}$ & $\geq 0.78$ & - & - \\
\hline
\end{tabular}

has some influence on the spatial distribution of local temperature: the low temperature area in the northwest of the water resource area decreases, while the central value of high temperature area in the Chengdu Plain in the east increases. In terms of the seasonal distribution, it has been observed that, after the reservoir construction, the local temperature will rise in summer and winter and slightly decrease in spring and autumn. It increases by approximately $0.28^{\circ} \mathrm{C}$ in winter.

2. Influence of the project on the local precipitation Through comparison of the simulation results of scenarios $\mathrm{A}$ and $\mathrm{C}$, the spatial distribution of local precipitation changes significantly in a changing environment, and the high-value center in the south of Tibet moves northward. The regional precipitation tends to decrease on the whole by approximately $56 \mathrm{~mm}$ in the average annual value; through comparison of scenarios $\mathrm{A}$ and $\mathrm{B}$, the reservoir construction has little impact on the local precipitation distribution under the current climate conditions. An increase of approximately $34 \mathrm{~mm}$ in the average annual precipitation is only detected in the east of Sichuan province below the dam sites; through comparison of scenarios $\mathrm{C}$ and $\mathrm{D}$, the reservoir construction exerts little impact on the regional average annual precipitation, which slightly increases by approximately $22 \mathrm{~mm}$. The spatial distributions of average annual precipitation under the four scenarios are shown in Fig. 4.

In terms of the seasonal distribution, the precipitation tends to decrease in winter, spring and autumn after the reservoir construction in future climate scenario, and the decrease by $19 \%$ in spring is the most significant, while the precipitation in summer increases by approximately $7 \%$. The change of the spatial distribution of precipitation before and after the reservoir construction in the future climate scenario is shown in Fig. 5.

\subsection{Impact evaluation on typical dewatered river reaches}

\subsubsection{Influence on the water amount of downstream river reaches}

According to the diversion scheme of 8 billion $\mathrm{m}^{3}$ water in the first stage of the western route project, the streamflow below the dam sites will significantly decrease after the operation of water transfer reservoirs. According to the monthly distribution plan with regard to discharge amount, it is in June that the main stream of Yalong River most suffers from water extraction, and the discharge amount of Reba reservoir in June only accounts for $11.0 \%$ of the mean monthly flow; the Xianshui River system also suffers from the most significant influence of the water transfer project in June, and the discharge amount of Aan and Renda reservoirs in June, compared with the mean monthly flow, decreases by $88.1 \%$ and $89.6 \%$, respectively; the Sequ River of Chuosijia River system, where the Luoruo reservoir is located, is most influenced by the water extraction in October, with its mean monthly flow decreased by $83.6 \%$; the Dukehe River, where Zhuanda reservoir is located, is most influenced in June, with the mean monthly flow decreased by $92.1 \%$; the Zumuzu River system was most influenced by the water extraction in May. The water reduction of some typical river sections below the dam sites is shown in Fig. 6. The effects of stream dewatering will decrease with downstream distance from the dam sites due to inflow of tributaries. The streamflow at Lianghekou section of Yalong River can recover to $55.2 \%$ of that before the water extraction; streamflow at the river mouth of Xianshui River, Chuosijia River and Zumuzu River can be recover to $76.6-86.3 \%$ of that before the water transfer.

\subsubsection{Influence on hydraulic indices of downstream river reaches}

After the construction of reservoirs, the downstream channel flow significantly decreases, correspondingly bringing 
(a) preci of $1993-2002$, ExA, mm

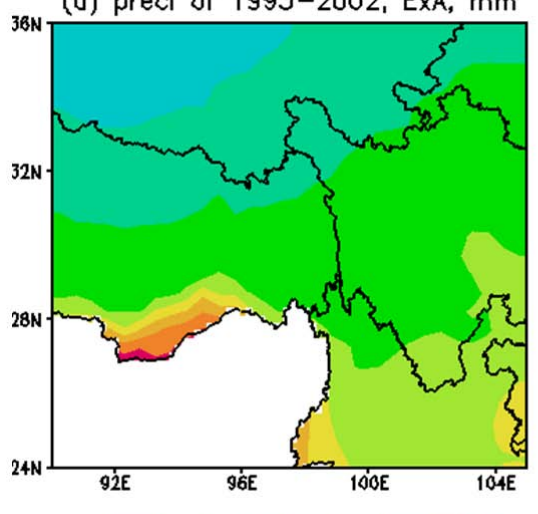

$\tau \frac{1}{0} \frac{1}{100} \quad \frac{1}{250} \frac{1}{500} \frac{1}{100012501500} \frac{1}{17502000}$

(c) preci 2040-2049, ExC, mm

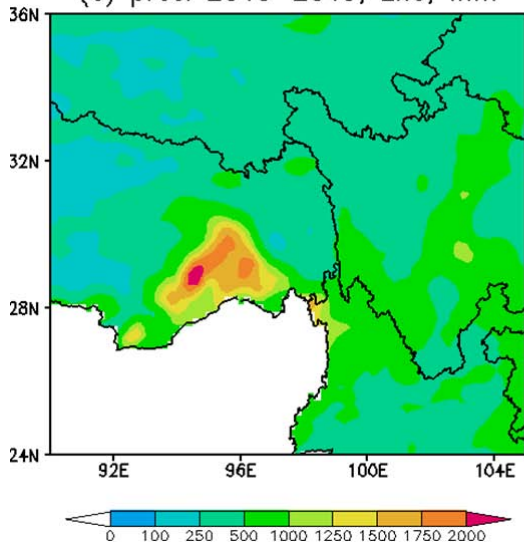

(b) preci of $1993-2002, E x B, \mathrm{~mm}$

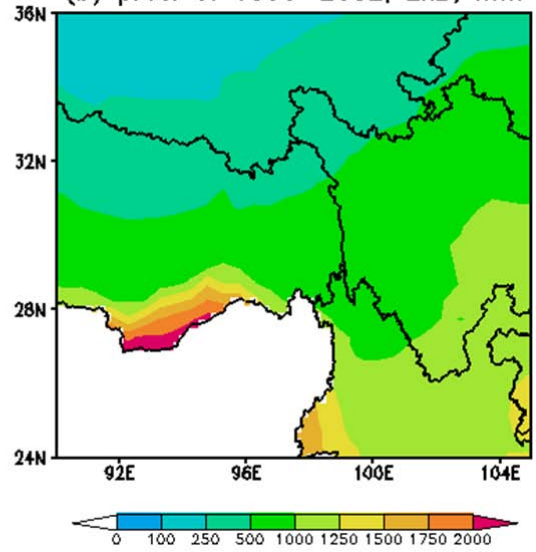

(d) preci 2040-2049, ExD, mm

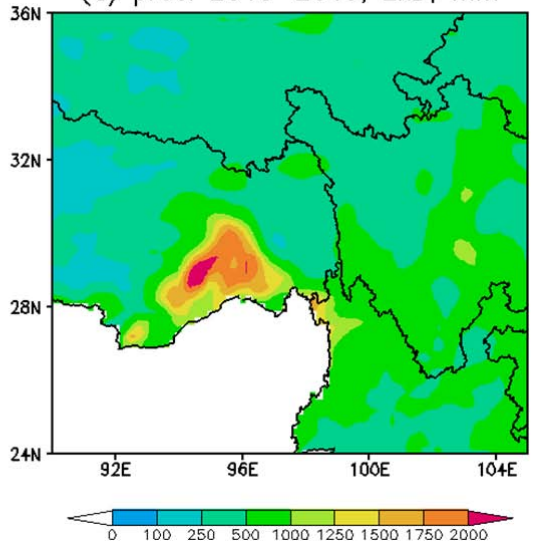

Fig. 4. The spatial distribution of average annual precipitation under the four scenarios. (a) 1993-2002 without reservoirs; (b) 1993-2002 with reservoirs; (c) 2040-2049 without reservoirs; (d) 2040-2049 with reservoirs.

dramatic changes to the water depth, flow velocity, water surface width as well as surface area of the dewatered river reaches. The Ganzi section in the Yalong River is such a case, which is approximately $96 \mathrm{~km}$ downstream from the Reba dam. The average annual flow in this section is influenced by about $50.7 \%$ by the water extraction. The mean monthly flow velocity after the water transfer is between $0.72 \mathrm{~m} \mathrm{~s}^{-1}$ and $1.44 \mathrm{~m} \mathrm{~s}^{-1}$, drastically reduced comparing with that before water transfer, especially during the rainy seasons. In the period of April to June when most fish species spawn, the mean flow velocity of the section will change from 1.11, 1.36 and $1.74 \mathrm{~m} \mathrm{~s}^{-1}$ to $0.82,0.97$ and $1.18 \mathrm{~m} \mathrm{~s}^{-1}$, with a decrease of $25.9,29.0$ and $32.4 \%$, respectively. The mean water surface width and water depth show a similar decrease after the water transfer, and they are close to the minimum monthly values on the whole (see Fig. 7). The change in physical habitat conditions will result in a certain impact on the river ecology, and ecological regulation is needed to satisfy the basic habitat requirement of fish species. Meanwhile, the amount of water flowing into the dewatered reaches rises because of tributary inflows with downstream distance from the dam, mitigating the impact of the water transfer on hydrological regime.

\subsection{Impact evaluation on the typical marsh wetlands}

According to the land use data in 2000 year, the total area of marsh wetlands in Yalong and Dadu River Basin is $765.11 \mathrm{~km}^{2}$. Approximately $70 \%$ of the wetlands is recharged via overland flow and hence out of the range of influence of the water extraction. Approximately $20 \%$ of the riverine wetlands is also not affected by water extraction, because they are located in the upstream regions far away from the dam sites, while the remaining $10 \%$ riverine wetlands near the dam sites will be partly affected by the project (Table 5). With the reservoir filling, the water level and surface width of the reservoir region rise, which may potentially change the recharge-discharge relationships between the river and riverine marshes. Water recharging effect from the riverside may be facilitated. Meanwhile, the flooding effect above the dam sites is enhanced; thus, the area of existing flooded marshes will increase and even new wetland will emerge. Therefore, the dam construction has a positive impact on these wetlands, accounting for $0.2 \%$ of the total area of marsh wetlands. The flooding effect will be weakened 

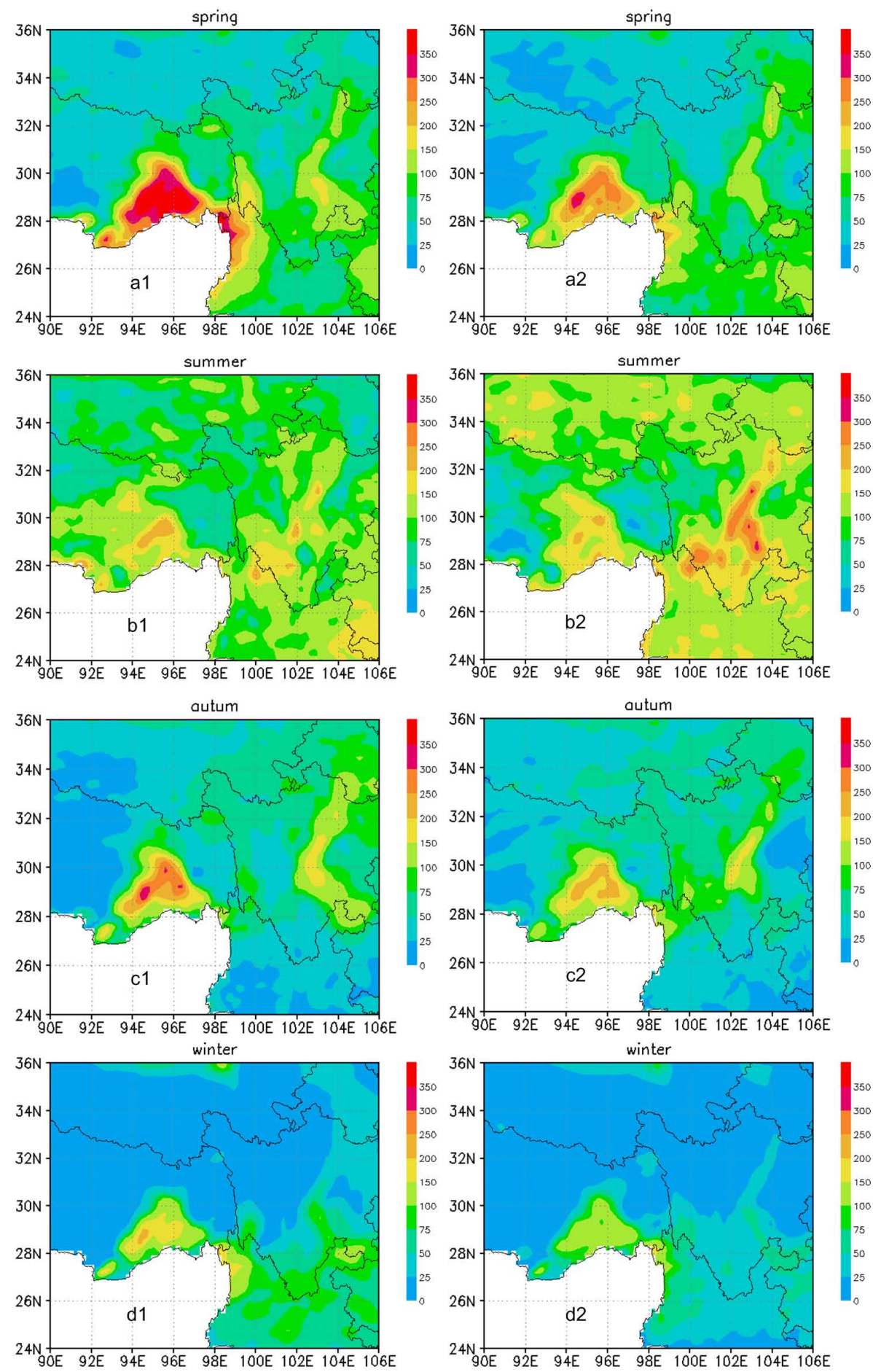

Fig. 5. The spatial distribution of seasonal average monthly precipitation of 2040-2049 under the scenarios of without reservoirs and with reservoirs(a1, b1, c1 and d1 - spring, summer, autumn and winter, respectively, without reservoirs; a2, b2, c2 and d2 - spring, summer, autumn and winter, respectively, with reservoirs).

below the dam sites due to dam regulation, negatively influencing approximately $5.0 \%$ of the wetland.

The hydrological factor is the most important environmental factor contributing to the scope, composition, structure and quality of the wetland. The change of hydrological regime is one of the most important driving forces of the environmental evolution in the wetland. Based on the model calculation, an analysis of landscape pattern evolution of the marsh wetlands in the water resource area, under both historical and future scenarios, was conducted. The results are listed 
Table 5. Integrated evaluation of the influence of the western route project on marsh wetlands.

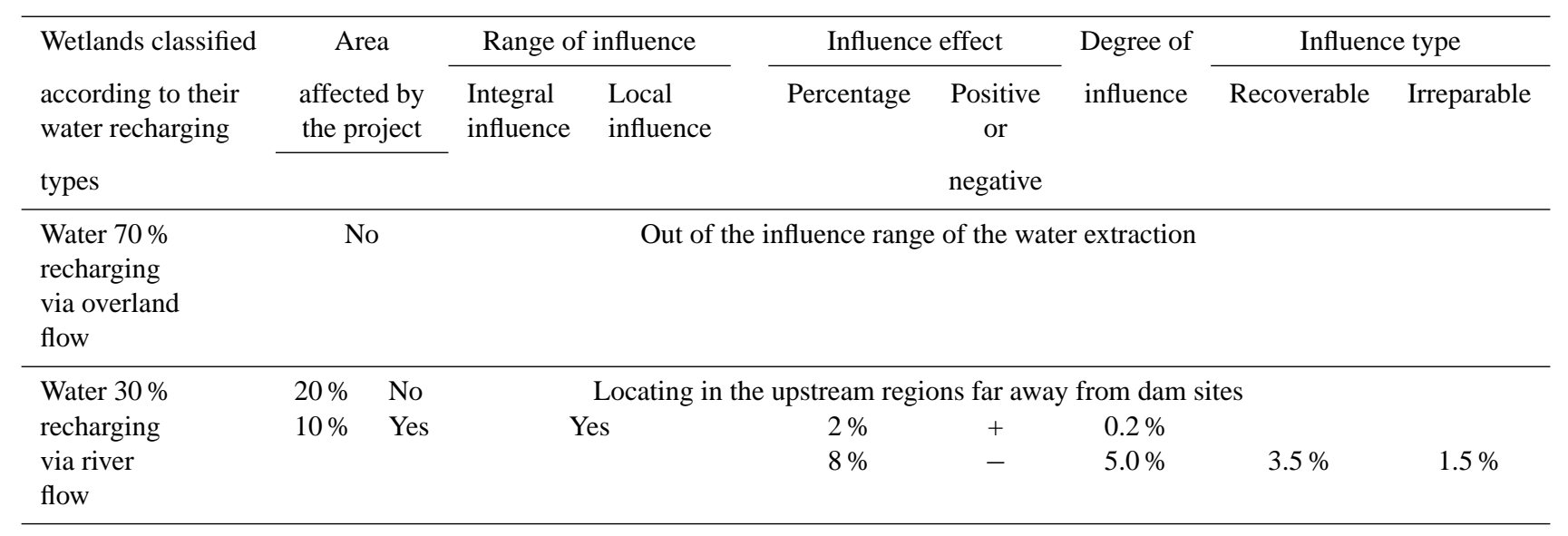

Note: “+” means a positive impact and "_" means a negative impact. The same below.
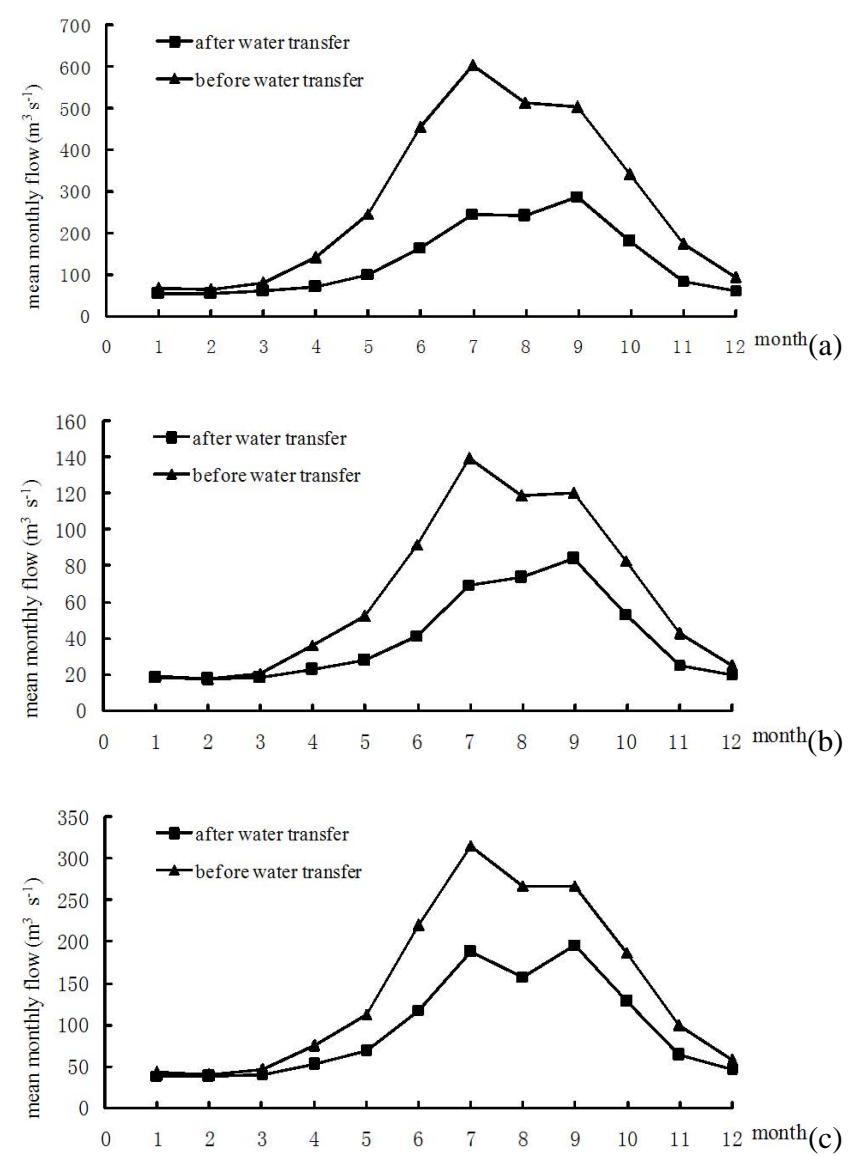

Fig. 6. Comparison of the mean monthly flow of some typical river sections before and after water transfer. (a) Ganzi section in Yalong River, (b) Zhuba section in Niqu River and (c) Daofu section in Xianshui River. in Table 6. Comparing the two historical scenarios, the landscape pattern of marsh wetlands shows obviously distinct evolution characteristics. During the period of 1980-2000, both the wetlands charging via overland flow and river flow increase in their areas accompanied by enhancement of the heterogeneity, connectivity and productivity on the whole, while during 2000-2009, the situation changes in the opposite direction. Both climate change and human activities play important roles in the wetland evolution, and their degrees of influence drastically vary in different phases. Under the future scenario without the project, the marsh wetlands will show a significant decrease mainly resulting from unreasonable human activities (accounting for $70 \%$ ). The project has an overall positive impact on the marsh wetlands under a changing environment. This indicates that the modification of microclimatic conditions due to reservoir construction may offset the degeneration of wetlands to some degree.

\subsection{Impact evaluation on the natural reserves}

During the construction phase of the project, a broad stretch of original forest vegetation will be permanently destroyed and can hardly be restored. After the completion of the water transfer reservoir, it is estimated that approximately 1651 ha of forest land and 2561 ha of shrub vegetation will be submerged. As a result, the rare medicinal plants and wild fungi resources as well as the natural habitats of wild animals will be damaged. What is more, the reservoir construction will inevitably result in the loss of fish biodiversity in view of blockage of migration routes and submergence of the torrent habitats and spawning places of fish. Though the newly formed reservoir wetlands may provide new habitats for species like waterfowl and wading birds, the natural wetland systems can not be replaced by the artificial ones because of the clear difference in physical and ecological functioning. After the water extraction, the amount of water available for ecological systems of such natural reserves as Xialatuo and Kasha Lake 


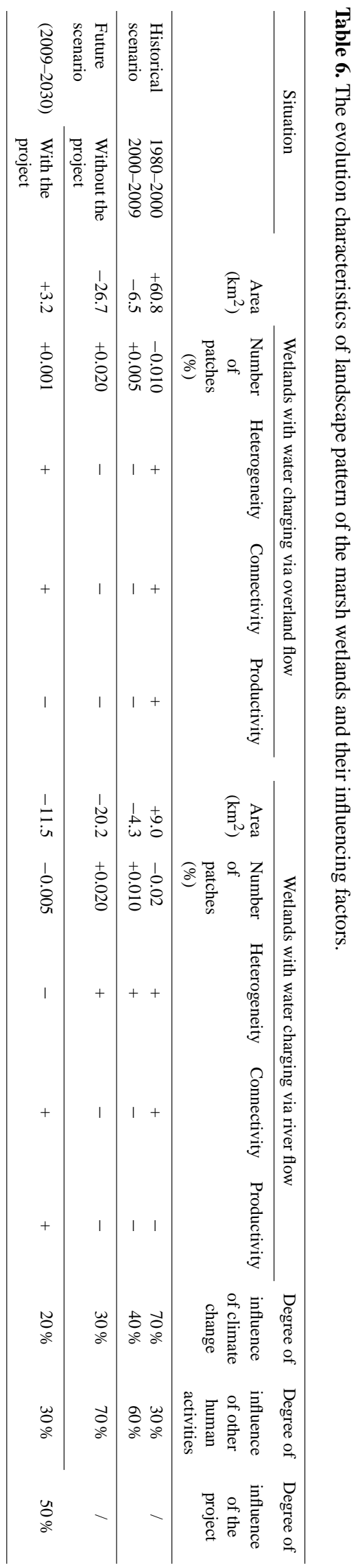



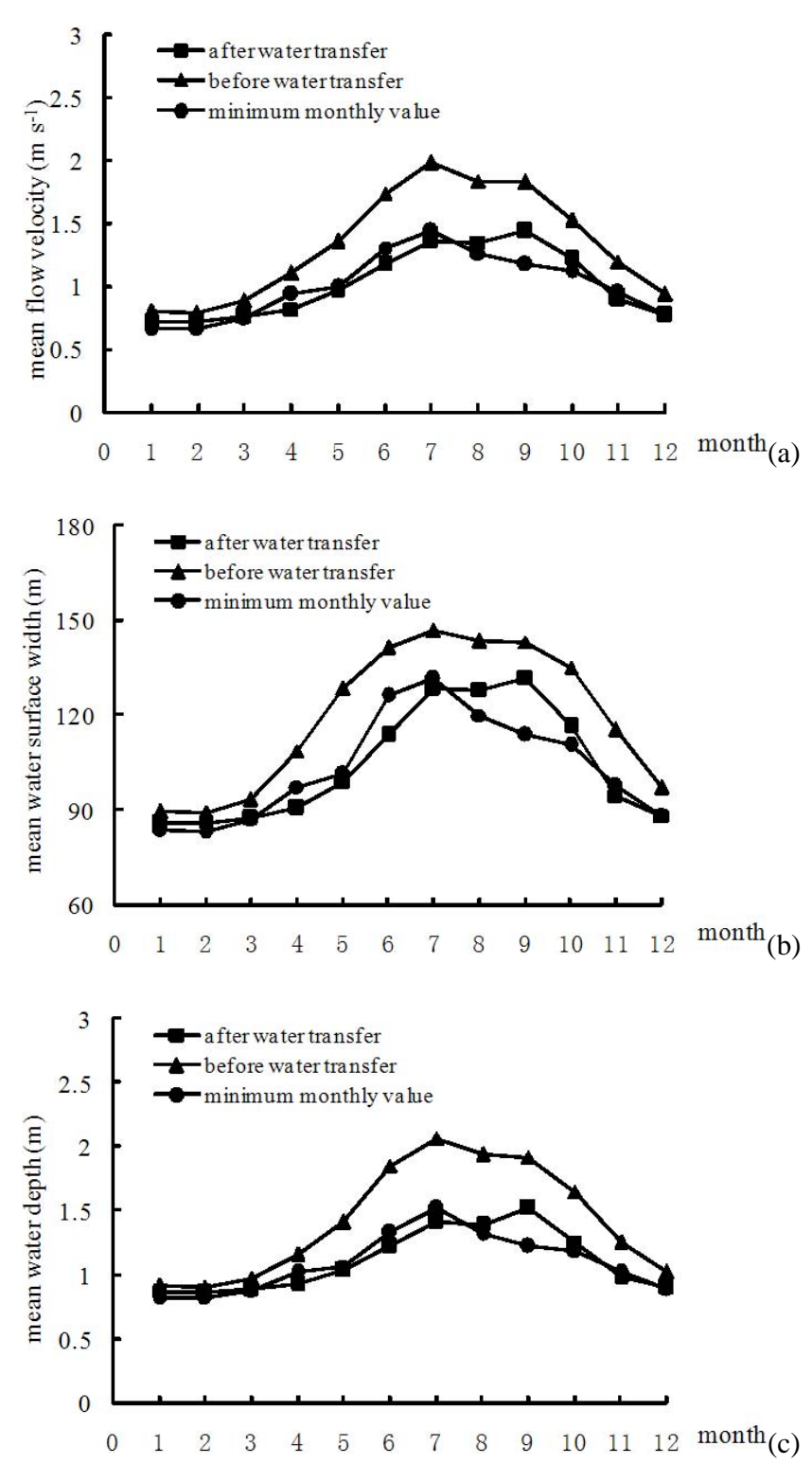

Fig. 7. Influence on the average flow velocity, water surface width and water depth at the Ganzi section of Yalong River. (a) Mean flow velocity, (b) mean water surface width and (c) mean water depth.

downstream from the dam will drastically decrease. However, with an ecological operation, the discharge flow can basically satisfy the ecological water requirement.

\subsection{Impact evaluation on the water environment below the dam sites}

\subsubsection{Influence on the water quality of main river reaches below the dam sites}

Given the change of socio-economic level, pollution discharge, and water resource allocation in different phases of development, the influence of water transfer on the water environment below the dam sites is discussed in three target years: 2010 (present), 2020 and 2030 (future). For the Ake River reaches, the five-day biochemical oxygen demand $\left(\mathrm{BOD}_{5}\right)$ can meet the standard I of surface water quality, and the chemical oxygen demand (COD) and ammonia- $\mathrm{N}\left(\mathrm{NH}_{3}-\right.$ $\mathrm{N}$ ) can meet the standard II in the three target years under the scenarios of water extraction, average annual flow and without consideration of pollution control. During the dry season in February, water quality above and below Aba county section on Ake River is different. In the target year of 2010, $\mathrm{BOD}_{5}$ can meet the standard I and both $\mathrm{COD}$ and $\mathrm{NH}_{3}-\mathrm{N}$ can meet the standard II for the whole reaches of Ake River after water extraction. The water quality will not show obvious change in the future target years of 2020 and 2030 for the Ake River reaches upstream from the Aba country section, while, the predicted values of the three indices show a distinct change for the reaches below the Aba section. In 2020, the water quality of the $79-\mathrm{km}$ reach from the Aba section to the Ake River mouth will degrade to the standard IV and standard III with a river length of $43 \mathrm{~km}$ and $36 \mathrm{~km}$, respectively. Comparing to the scenario without water extraction, the maximum values of the concentration of $\mathrm{BOD}_{5}, \mathrm{COD}$ and $\mathrm{NH}_{3}-\mathrm{N}$ in Aba section increase by 13, 4 and $24 \%$, respectively. And the reach length of standard IV increases by $18 \mathrm{~km}$. In 2030, the water quality in the Aba county section will degrade to the standard $\mathrm{V}$, and the water quality of the whole $79-\mathrm{km}$ reach will merely meet the standard IV. The maximum values of $\mathrm{BOD}_{5}, \mathrm{COD}$ and $\mathrm{NH}_{3}-\mathrm{N}$ in Aba section increase by 13,3 and $8 \%$, respectively, and the reach length of standard IV increases by $9 \mathrm{~km}$ compared to the scenario without water extraction. On the whole, without pollution control, the water extraction will significantly degrade the water quality below the Aba section with a relatively high pollution load. The limit values of $\mathrm{COD}, \mathrm{BOD}_{5}$ and $\mathrm{NH}_{3}-\mathrm{N}$ for different water categories are extracted from the environmental quality standards for surface water of China (GB 3838-2002), as shown in Table 7.

With pollution control, the water quality will be significantly improved. During the dry season in February, the $\mathrm{BOD}_{5}$ can meet the standard I and both $\mathrm{COD}$ and $\mathrm{NH}_{3}-\mathrm{N}$ can meet the standard II for the whole reaches of Ake River except the Aba country section, in the future target years of 2020 and 2030. The concentration of BOD 5 in Aba county section slightly exceeds the standard II and is in line with the standard III. The result indicates that the water quality can be raised by 1-2 levels with the implementation of pollution control measures. The water quality of Ake River reaches in February under different scenarios is shown in Fig. 8.

The water quality of the other seven rivers will not show significant degeneration in the three target years after the water extraction. It can still meet the standard II of surface water quality without pollution control. The concentration of $\mathrm{NH}_{3}$ $\mathrm{N}$ in reaches downstream from the dams will significantly decrease by $27-41 \%$ in the initial stage of the rainy season. The purification effect of the water transfer reservoirs tends 
Table 7. The limit values of $\mathrm{COD}, \mathrm{BOD}_{5}$ and $\mathrm{NH}_{3}-\mathrm{N}$ for the surface water quality standards unit $\left(\mathrm{mg}^{-1}\right.$.)

\begin{tabular}{llllll}
\hline Items & Standard I & Standard II & Standard III & Standard IV & Standard V \\
\hline $\mathrm{COD} \leq$ & 15 & 15 & 20 & 30 & 40 \\
$\mathrm{BOD}_{5} \leq$ & 3 & 3 & 4 & 6 & 10 \\
$\mathrm{NH}_{3}-\mathrm{N} \leq$ & 0.15 & 0.5 & 1.0 & 1.5 & 2.0 \\
\hline
\end{tabular}
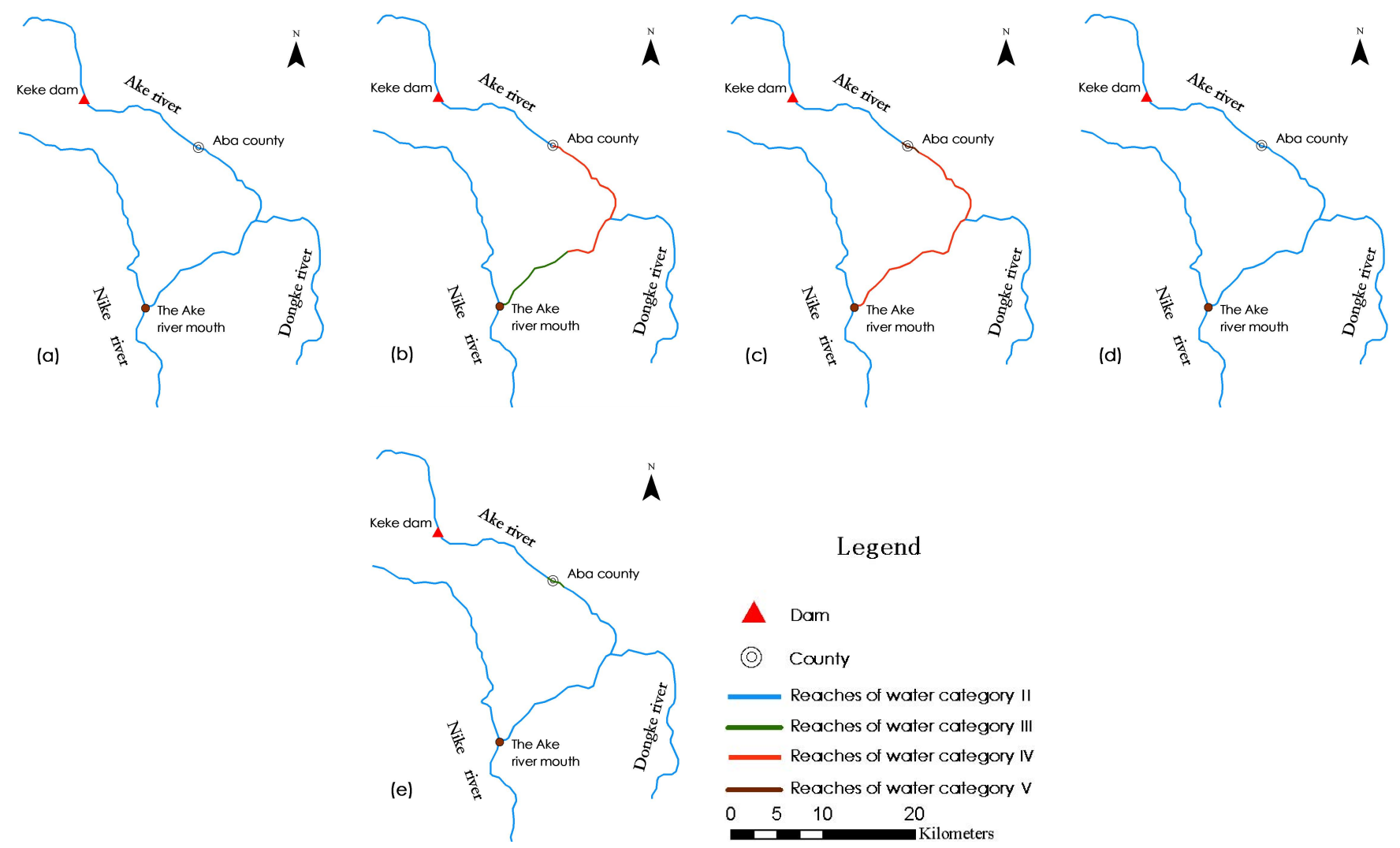

Legend

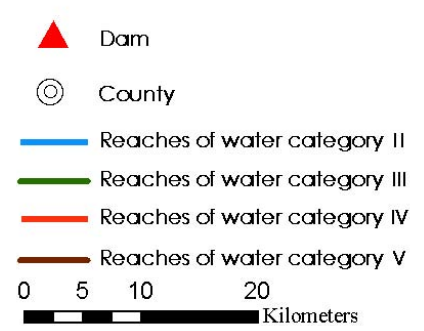

Fig. 8. The water quality of Ake River reaches below the dam sites in February under different scenarios. (a), (b), (c) The three target years of 2010, 2020 and 2030, respectively, without pollution control; (d) 2010 with pollution control, (e) 2020 and 2030 with pollution control.

to reduce the ammonia pollution in the river reaches below the dam sites and improve the water quality to some degree.

\subsubsection{Influence on the water environmental capacity in the county sections}

Based on the water quality objective (standard II) of water function zoning, the influence of water extraction on the capacity of water environment in the county sections is analyzed. The water environmental capacity of $\mathrm{COD}$ and $\mathrm{NH}_{3}$ $\mathrm{N}$ decreases by $13-32 \%$ resulting from a substantial reduction in the river flows after the water extraction. The Ake River, the most sensitive river to the water reduction, will suffer from a serious water quality problem, and the pollution control measures are needed. However, the surplus capacity of water environment of the other rivers related to the water transfer project remains high. This indicates that the project overall has a limited effect on the water environmental capacity of reaches below the dam sites.

\subsection{Overall evaluation of the comprehensive influence}

On the basis of the results of single-item evaluation, the degrees of influence of each influencing items were classified by the expert estimation system. Overall evaluation of the comprehensive environmental impact of the western route project of SNWTP is intuitively shown in Figs. 9 and 10. The color sectors are related to a scale of impact, and the sectors of the outside lanes indicate a higher impact scale than that of inside ones.

In general, the major environmental impacts of the project lie in the permanent destruction of vegetation during the phase of dam construction and river impoundment as well as the significant impact on the hydrological situation of the 


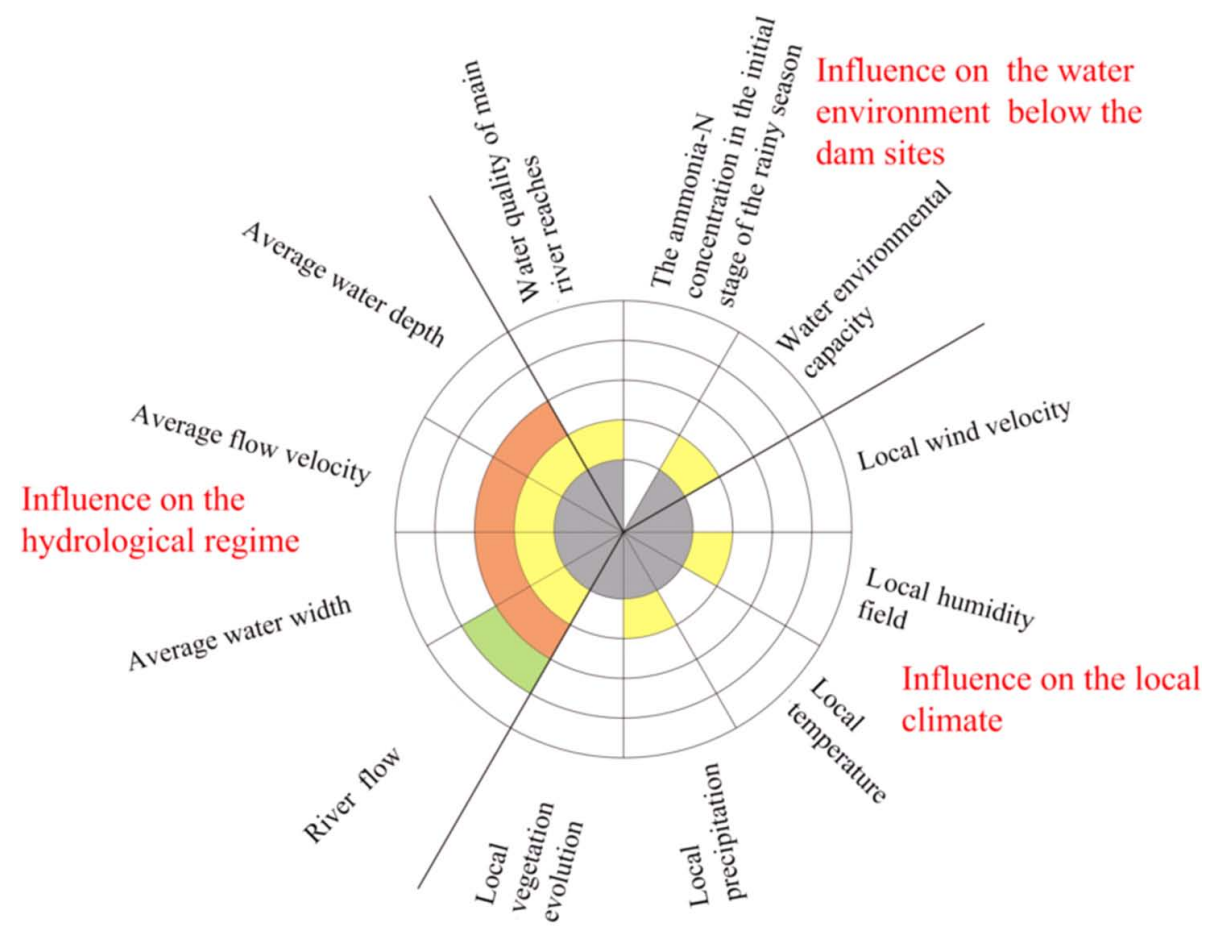

Fig. 9. Overall evaluation of the comprehensive environmental impact of the project (1).

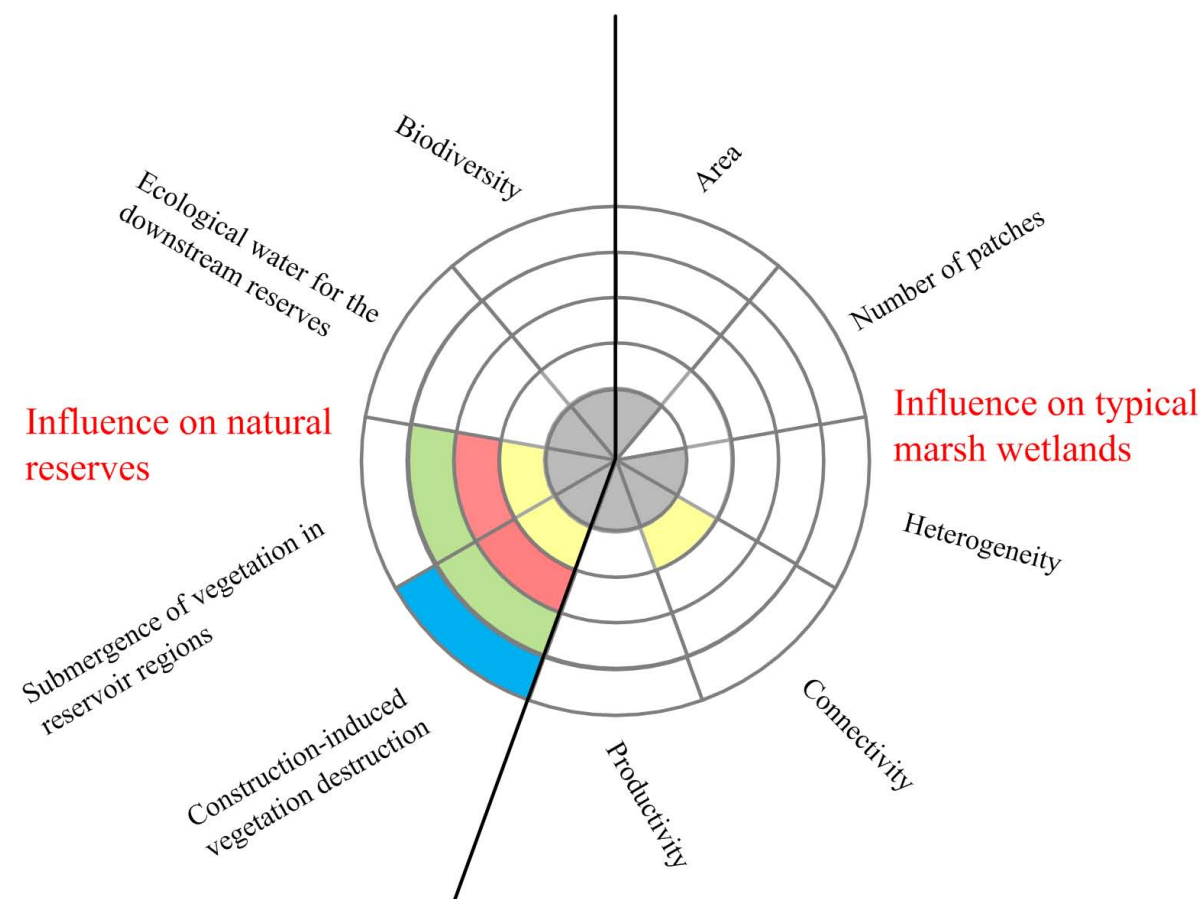

Fig. 10. Overall evaluation of the comprehensive environmental impact of the project (2). 
river corridors after the implementation of water extraction. The influence on local climate and vegetation, typical marsh wetlands, natural reserves and water environment below the dam sites is limited.

\section{Conclusions}

Based on the practical needs of the impact evaluation of the western route project of SNWTP in a changing climate and supported by a climate-hydrology-ecology coupled simulation model, quantitative analysis on three different scales of space has been undertaken, focusing on local climate, typical dewatered river reaches, typical marsh wetlands, natural reserves and the water environment downstream from the dam sites. The conclusions are as follows:

1. The influence on the local climate of the water resource area: the reservoir construction has little influence on the wind speed and temperature in the water resource area. While a relatively significant change in the regional humidity field and precipitation distribution is observed under the changing environment with the reservoir construction, the average annual rainfall increases by approximately $22 \mathrm{~mm}$.

2. The influence on typical dewatered river reaches: after the water extraction, the downstream channel flow will suffer from a sharp decrease, accompanied by the drastic change of hydraulic indices of the water depth, the flow velocity, the water surface width and surface area. The altering hydrological regime results in a certain impact on the river ecology. Meanwhile, the amount of water flowing into the dewatered reaches rises due to tributary inflows with downstream distance from the dam, mitigating the negative impact of water reduction..

3. The influence on typical marsh wetlands: approximately $10 \%$ of riverine wetlands near the dam sites will be partly affected by the project. The enhanced flooding effect and water recharging effect from the riverside may positively increase the area of wetlands above the dam sites. The project seems to have an overall positive impact on the marsh wetlands under a changing environment because of the reservoir-induced modification of microclimatic conditions.

4. The influence on natural reserves: the constructioninduced vegetation destruction and submergence of vegetation in the reservoir regions will inevitably damage the biodiversity in the natural reserves. Though the newly formed reservoir wetlands may provide new habitats for species like waterfowl and wading birds, their impact on the biodiversity is uncertain.

5. The influence on the water quality of the lower reaches: the water extraction has a significant effect on the water quality of Ake River especially in the Aba county section due to a high pollution load and a reduced water environmental capacity. The water quality level can be apparently raised with the implementation of pollution control measures. The water quality of the other seven rivers with relatively high surplus capacities of water environment will not show significant degeneration. In addition, the concentration of ammonia in the initial stage of rainy season shows a dramatic decrease by $27-$ $41 \%$ with the purification effect of the water transfer reservoirs.

Acknowledgements. The authors would like to thank the the guest editor and two anonymous reviewers for their helpful comments, which improved the quality of the final manuscript. This study is jointly funded by the National Key Project of Scientific and Technical Supporting Program (Grant No. 2006BAB04A08) and Innovation Research Group Foundation Programme of Natural Science Foundation of China (Grant No. 51021066).

Edited by: A. Ghadouani

\section{References}

Baran, E. and Myschowoda, C.: Dams and fisheries in the Mekong Basin, Aquat. Ecosyst. Health, 12, 227-234, 2009.

Berkoff, J.: China: The South-North Water Transfer Project - is it justified?, Water Policy, 5, 1-28, 2003.

Bombino, G., Tamburino, V., and Zimbone, S. M.: Assessment of the effects of check-dams on riparian vegetation in the mediterranean environment: a methodological approach and example application, Ecol. Eng., 27, 134-144, 2006.

Braatne, J. H., Rood, S. B., Goater, L. A., and Blair, C. L.: Analyzing the impacts of dams on riparian ecosystems: a review of research strategies and their relevance to the Snake River through Hells Canyon, Environ. Manage., 41, 267-281, 2008.

Brismar, A.: Attention to impact pathways in EISs of large dam projects, Environ. Impact Assses., 24, 59-87, 2004.

Burke, M., Jorde, K., and Buffington, J. M.: Application of a hierarchical framework for assessing environmental impacts of dam operation: Changes in streamflow, bed mobility and recruitment of riparian trees in a western North American river, J. Environ. Manage., 90, 224-236, 2009.

Casado, C., Carcia de Jalon, D., Delolmo, C. M., Barcelo, E., and Menes, F.: The effect of an irrigation and hydroelectric reservoir on its downstream communities, Regul. River., 4, 275-284, 1989.

Davies, B. R., Thoms, M., and Meador, M.: An assessment of the ecological impacts of interbasin water transfers, and their threats to river basin integrity and conservation, Aquat. Conserv., 2, 325-349, 1992.

Döll, P. and Zhang, J.: Impact of climate change on freshwater ecosystems: a global-scale analysis of ecologically relevant river flow alterations, Hydrol. Earth Syst. Sci., 14, 783-799, doi:10.5194/hess-14-783-2010, 2010. 
Doledec, S., Dessaix, J., and Tachet, H.: Changes within the Upper Rhone River macrobenthic communities after the completion of three hydroelectric schemes: anthropogenic effects or natural change?, Arch. Hydrobiol., 136, 19-40, 1996.

Friedl, G. and Wüst, A.: Disrupting biogeochemical cycles: consequences of damming, Aquat. Sci., 64, 55-65, 2002.

Ghassemi, F. and White, I.: Inter-Basin Water Transfer: Case studies from Australia, United States, Canada, China, and India, Cambridge Univ. Press, New York, 2006.

Graf, W. L.: Downstream hydrologic and geomorphic effects of large dams on American rivers, Geomorphology, 79, 336-360, 2006.

Growns, I., Reinfelds, I., Williams, S., and Goade, G.: Longitudinal effects of a water supply reservoir (Tallowa Dam) on downstream water quality, substrate and riffle macroinvertebrate assemblages in the Shoalhaven River, Australia, Mar. Freshwater Res., 60, 594-606, 2009.

Hu, W. W., Wang, G. X., Deng, W., and Li, S.: The influence of dams on ecological conditions in the Huaihe River basin, China, Ecol. Eng., 33, 233-241, 2008.

Ji, J. F., Shen, J., Balsam, W., Chen, J., Liu, L. W., and Liu, X. Q.: Asian monsoon oscillations in the northeastern QinghaiTibet Plateau since the late glacial as interpreted from visible reflectance of Qinghai Lake sediments, Earth Planet. Sc. Lett., 233, 61-70, 2005.

Jia, Y. W., Ni, G. H., Kawahara, Y., and Suetsugi, T.: Development of WEP model and its application to an urban watershed, Hydrol. Process., 15, 2175-2194, 2001.

Jones, J. W., Hoogenboomb, G., Porter, C. H., Boote, K. J., Batchelor, W. D., Hunt, L. A., Wilkens, P. W., Singh, U., Gijsman, U., and Ritchie, J. T.: The DSSAT cropping system model, Eur. J. Agron., 18, 235-265, 2003.

Kittinger, J. N., Coontz, K. M., Yuan, Z. P., Han, D. J., Zhao, X. F., and Wilcox, B. A.: Toward holistic evaluation and assessment: linking ecosystems and human well-being for the Three Gorges Dam, Ecohealth, 6, 601-613, 2009.

Koutsos, T. M., Dimopoulos, G. C., and Mamolos, A. P.: Spatial evaluation model for assessing and mapping impacts on threatened species in regions adjacent to Natura 2000 sites due to dam construction, Ecol. Eng., 36, 1017-1027, 2010.

Liang, X. Z., Choi, H., Kunkel, K. E., Dai, Y., Joseph, E., Wang, J. X. L., and Kumar, P.: Development of the regional climate-weather research and forecasting model (CWRF): Surface boundary conditions, Illinois State Water Survey Scientific Research, ISWS SR 2005-01, Springfield, 2005a.

Liang, X. Z., Xu, M., Zhu, J., Kunkel, K. E., and Wang, J. X. L.: Development of the regional climateweather research and forecasting model (CWRF): Treatment of topography, in: Proceedings of 2005 WRF/MM5 User's Workshop, Boulder, CO, 2005b.

Liang, X. Z., Xu, M., Yuan, X., Ling, T., Choi, H. I., Zhang, F., Chen, L., Liu, S., Su, S., Qiao, F., He, Y., Wang, J. X. L., Kunkel, K. E., Gao, W., Joseph, E., Morris, V., Yu, T. W., Dudhia, J., and Michalakes, J.: Regional Climate-Weather Research and Forecasting Model (CWRF), B. Am. Meteorol. Soc., doi:10.1175/BAMS-D-11-00180.1, in press., 2012.

Ligon, F. K., Dietrich, W. E., and Trush, W. J.: Downstream ecological effects of dams, Bioscience, 45, 183-192, 2011.

Liu, X. D. and Chen, B. D.: Climatic warming in the Tibetan Plateau during recent decades, Int. J. Climatol., 20, 1729-1742, 2000.
Meador, M. R.: Inter-basin Water Transfer: Ecological Concerns, Fisheries, 17, 17-22, 1992.

Moiwo, J. P., Yang, Y. H., Li, H. L., Han, S. M., and Yang, Y. M.: Impact of water resource exploitation on the hydrology and water storage in Baiyangdian Lake, Hydrol. Process., 24, 3026-3039, 2010.

Morais, P.: Review on the major ecosystem impacts caused by damming and watershed development in an Iberian basin (SWEurope): focus on the Guadiana estuary, Ann. Limnol.-Int. J. Lim., 44, 105-117, 2008.

Nardini, A., Blanco, H., and Senior, C.: Why didn't EIA work in the Chilean project canal lajadiguillın?, Environ. Impact Assess., 17, 53-63, 1997.

Olden, J. D. and Naiman, R. J.: Incorporating thermal regimes into environmental flows assessments: modifying dam operations to restore freshwater ecosystem integrity, Freshwater Biol., 55, 86$107,2010$.

Oleson, K. W., Dai, Y., Bonan, G., Bosilovich, M., Dickinson, R., Dirmeyer, P., Hoffman, F., Houser, P., Levis, S., Niu, G. Y., Thornton, P., Vertenstein, M., Yang, Z. L., and Zeng, X.: Technical description of the Community Land Model (CLM), Tech. Rep. NCAR/TN-461+STR, National Center for Atmospheric Research, Boulder, CO, 2004.

Ouyang, W., Hao, F. H., Song, K. Y., and Zhang, X.: Cascade DamInduced Hydrological Disturbance and Environmental Impact in the Upper Stream of the Yellow River, Water Resour. Manag., 25, 913-927, 2011.

Pal, J. S., Giorgi, F., Bi, X., Elguindi, N., Solmon, F., Gao, X., Rauscher, S. A., Francisco, R., Zakey, A., Winter, J., Ashfaq, M., Syed, F. S., Bell, J. L., Diffenbaugh, N. S., Karmacharya, J., Konar, A., Martinez, D., da Rocha, R. P., Sloan, L. C., and Steiner, A. L.: Regional climate modeling for the developing world, The ICTP RegCM3 and RegCNET, B. Am. Meteorol. Soc., 88, 1395-1409, 2007.

Petts, G. E.: Impounded rivers: perspectives for ecological management, Wiley, Chichester, UK, 1984.

Pittock, J. and Finlayson, C. M.: Australia's Murray-Darling Basin: freshwater ecosystem conservation options in an era of climate change, Mar. Freshwater Res., 62, 232-243, 2011.

Poff, N. L., Allan, J. D., Bain, M. B., Karr, J. R., Prestegaard, K. L., Richter, B. D., Sparks, R. E., and Stromberg, J. C.: The natural flow regime: a paradigm for river conservation and restoration, Bioscience, 47, 769-784, 1997.

Restrepo, J. D. and Cantera, J. R.: Discharge diversion in the Patía River delta, the Colombian Pacific: Geomorphic and ecological consequences for mangrove ecosystems, J. S. Am. Earth Sci., doi:10.1016/j.jsames.2011.04.006, in press, 2011.

Rosenberg, D. M., Berkes, F., Bodaly, R. A., Hecky, R. E., Kelly, C. A., and Rudd, J. W. M.: Large-scale impacts of hydroelectric development, Environ. Rev., 5, 27-54, 1997.

Saaty, R. W.: The analytic hierarchy process - what it is and how it is used, Math. Model., 9, 161-176, 1987.

Shah, Z. and Kumar, M. D.: In the midst of the large dam controversy: objectives, criteria for assessing large water storages in the developing world, Water. Resour. Manage., 22, 1799-1824, 2008.

Steffen, W. L., Cramer, W., Matthias, P., and Bugmann, H.: Global vegetation models: incorporating transient changes to structure and composition, J. Veg. Sci., 7, 321-328, 1996. 
Wang, G. Q.: World water transfer projects, Beijing, Science Press, 2009.

Wu, N., Tang, T., Fu, X., Jiang, W., Li, F., Zhou, S., Cai, Q., and Fohrer, N.: Impacts of cascade run-of-river dams on benthic diatoms in the Xiangxi River, China, Aquat. Sci., 72, 117-125, 2010.

Xu, X. B., Tan, Y., Yang, G. S., Li, H. P., and Su, W. Z.: Impacts of China's Three Gorges Dam Project on net primary productivity in the reservoir area, Sci. Total Environ., 409, 4656-4662, 2011.

Yang, L. X.: Foreign water transfer projects, Beijing, China Water Power Press, 2003.
Yang, S. T., Liu, C. M., Yang, Z. F., Sun, R., and Zhou, X. D.: Natural Eco-environmental Evaluation of West Route Area of Interbasin Water Transfer Project, Acta Geogr. Sin., 57, 11-18, 2002.

Yuan, X. and Liang, X. Z.: Improving cold season precipitation prediction by the nested CWRF-CFS system, Geophys. Res. Lett., 38, L02706, doi:10.1029/2010GL046104, 2011.

Zeilhofer, P. and de Moura, R. M.: Hydrological changes in the northern Pantanal caused by the Manso dam: Impact analysis and suggestions for mitigation, Ecol. Eng., 35, 105-117, 2009.

Zhao, Y., Lu, C. Y., and Xiao, W. H.: Study on rational deployment of generalized water resources, II. Model, SHUILI XUEBAO, 38, 163-170, 2007. 